\title{
Telling the Truth About Women's Lives
}

\author{
Ailbhe Smyth
}

Copyright (c) 2015 by Ailbhe Smyth. This text may be archived and redistributed both in electronic form and in hard copy, provided that the author and journal are properly cited and no fee is charged for access.

\section{Tell us, they say, about women and abortion in} Ireland.

I'm not sure that I can any more, or at least not in any straightforward way. There are several reasons for this, personal as much as political. I'm not sure which is the most complicated, and in any case (in my case), the reasons are peculiarly resistant to partition. One way and another, I suspect it's to do with the passage of time, the transmutations of generations and, above all, how abortion is framed and dealt with in Ireland.

But it's not in Ireland, abortion, that's the whole point. If it were, we wouldn't be here having to write about it. Again. Or think about it, or not much, or not so endlessly. It's Byzantine, this matter of abortion, convoluted, complex beyond all reason and necessity, harrowing, tortuous. Also often wounding, and sometimes bizarre. ${ }^{1}$

As I'm writing this, keeping an ear to the ground as ever, I hear a bishop speak. He says, inter alia, that lesbians and gay men who have children may be care-givers, but they "are not necessarily parents". When asked about his views on a woman having an abortion after she has been raped, the bishop says women who become pregnant through rape should not "destroy a life in order to get back at the rapist". ${ }^{2}$ That these models of logic aroused

1. The footnotes rev up in my head as soon as I start to write. Speaking on the barricades is different why? There's a hitch in there already.

2. Interview with the Bishop of Elphin, Kevin ·/. more amusement and caustic comment than ire and offence is a sign of the rapid and steep decline of the power of the Catholic Church in Ireland over the past 20 years. The bishop's intervention in a secular debate is seen as contentious and out of step with contemporary morality and behaviour. It is counter-cultural. Irish people are no longer cowed or obsequious in the face of episcopal intimidation. And we're certainly not obedient. Mostly, we don't believe the bishop, and definitely we don't do what the bishop says.

To be fair (although I'm under no obligation, given our history of subjugation by the Catholic clergy), the next day, other bishops and priests rushed quasi en masse to dissociate themselves from the bishop's remarks, and he had to apologise for any hurt he 'may' have caused, which is more of a damage limitation exercise than an apology. Mind you (I'm still being fair), it wasn't the abortion remarks the hastening clergy were repudiating, only the comments on the parenting suitability of lesbians and gay men, considered as potentially damaging to the Catholic Church in light of the marriage equality referendum to be held in May. So a strategic partial repudiation then. Nothing to do with truth.

All the same, it's a change that changes so much, after generations of feminism, we know

\footnotetext{
./ Doran, on Newstalk 106, 9/03/15. See report in The Irish Times 10/03/15. Available at http://www.irishtimes.com/news/social-affairs/ religion-and-beliefs/bishop-opposed-to-same-sexmarriage-struggled-with-sexuality-1.2132250.
} 
a lot more now about the truths of women's lives, and we're talking about them, not sub rosa and entre nous, but out loud and in public.

I grew up knowing nothing. No one ever told me the 'facts of life', and I'm not sure when I even knew there were facts I didn't know. Until quite a ripe age, sex and reproduction remained largely a mystery for me. In my convent school when I was about fourteen or fifteen, a nun told us, in all seriousness, that if we met boys (and we did, of course we did), we should keep our berets and gloves on all the time. For me, and for so many women of my generation and generations before me, you had to learn on the job. Trial and error. The consequences of the errors were always left to us, the women, to bear. These were the wages of sin, because sex (outside marriage) and sin were synonymous. Hence the Magdalen laundries, followed, in so many cases, by the lonely boat to England and life-long damage. As a young woman, I was lucky not to get pregnant. It wasn't because I was well-informed and well equipped - or practicing chastity. Au contraire. I was just lucky, that's all.

The silence surrounding abortion in this country has been deafening, only punctuated every decade or so by a dreadful human tragedy - the loss of a woman's life or the awful public drama of court cases taken to wrest from the State the right to access abortion here, where we live. It has been a silence where women cannot talk of their experiences, and where even to fight for women's right to abortion has meant being branded as a kind of outlaw.

\section{"What would happen if one woman told the truth about her life?",}

If we had abortion right here and now, we'd be talking about it differently, in a more ordinary way, as neither more nor less momentous than other events and experiences in the life of a woman. ${ }^{4} \mathrm{We}$ 'd be talking about it if and when we needed or wanted to, nor to satisfy the relentless probing of (certain) media for 'true life' abortion dramas. It's an irony, that: all over the media if you're an extreme case, but better shut up if you've had a routine

3. Muriel Rukeyser: "Käthe Kollwitz" (1968) in The Collected Poems of Muriel Rukeyser. 2005. Pittsburgh: Pittsburgh University Press, 460-4. abortion or taken the abortion pill because you don't want to have a baby. Maybe never, maybe no more children, maybe later, maybe certainly later. But not now.

Truth may not be the better part of valour, but it is our only hope.

We have to break that suffocating silence and speak plainly. We have to call a spade a spade and an abortion an abortion.

The thing is that abortion shouldn't be an 'issue' at all. Having your appendix out or your varicose veins removed are not 'issues' (except maybe in medical research. I don't know anything about that). You don't see many documentaries or read books or blog posts about people's experiences of these routine medical procedures. They are unsensational, not matters of public debate, argument and intense scrutiny. Morality doesn't come into play. They're not about right or wrong, but rather taken for granted as everyday necessities or choices ('election', to be precise, as in 'elective surgery'). The law doesn't come into it. To be sure, medical practice is regulated, but routine procedures are not subject to detailed enumeration, regulation, or surveillance by the forces of law and order. Abortion is the extremely rare, if not unique, exception. In Ireland anyway.

The plain fact of the matter is that abortion is not everywhere a 'dilemma for the nation', not everywhere as controversial and divisive, not everywhere so profoundly stigmatised and silenced. Other facts follow from this: abortion is one of the most commonly carried out medical procedures, ${ }^{5}$ and, where it is legal, it is also one of the safest. ${ }^{6}$ Even for women from, although not 'in', Ireland. Of course, what 'our' Irish abortion rate is I can't say, because abortion

4. Women have abortions every day. It's just one choice. Video made by Katie Gillum for the Irish Family Planning Association. Available at: https://www.youtube.com/watch?v=R4SSHkgD73E

5. The Guttmacher Institute estimates that globally between $30-40 \%$ of pregnancies end in abortion. The figures vary across different parts of the world and depending on whether abortion is safe and legal, prohibited or effectively unavailable. Guttmacher observes that highly restrictive abortion laws are not associated with lower abortion rates. The Irish abortion rate is somewhere between 1 in 9 or 1 in 10 . 
technically doesn't exist here, medically, legally or statistically, unless a woman's life is in danger or she is suicidal. ${ }^{7}$ Even in these appalling situations, the law is so restrictive and punitive, as well as baffling and intractable, that it continues to have a 'chilling' effect on the medical profession. ${ }^{8}$

"Ciunas! Ciunas! ${ }^{9}$ I can't hear myself speak!" My mother used to say (there were six of us, an unruly mob).

Inside my head, there's a cacophony of facts and stories, sedimented over three or four decades of struggle for the right to control our bodies and our reproductive lives. I try to sort it all out for myself, because I want to honour them, these women denied their right to freely decide for themselves, because their lives matter, and because the withholding of a human right to one of us, matters to all of us.

I think of how my own adult life has been scarred by the ugliness and rancour of those bitterly fought decennial referendums, in 1983, 1992 and 2002. Because of the Eighth Amendment, inscribed in the Constitution in 1983, we have one of the harshest abortion regimes in Europe. ${ }^{10}$ Despite the recurring referendums, the option to vote in favour of

6. Sadly, nearly half of all abortions worldwide are unsafe, and nearly all unsafe abortions (98\%) occur in developing countries. In the developing world, $56 \%$ of all abortions are unsafe, compared with just $6 \%$ in the developed world. Available at: http://www.guttmacher.org/pubs/fb_IAW.html

7. The Protection of Life During Pregnancy Act 2013 legalised abortion where a woman is suicidal, although the Act imposes a draconian interrogation regime which vests the power of decision in up to six doctors (gynaecologists / obstetricians, and psychiatrists). The Eighth Amendment to the Constitution, which equates the life of the woman ("mother") with that of the foetus ("the unborn") remains in full force, requiring the woman's life to be saved only in so far as it is "practicable" to do so. Failure to observe the law can result in up to 14 years imprisonment for the woman or for any person acting "with the intent to destroy unborn human life."

8. See judgment in the European Court of Human Rights landmark case: A, B and C v Ireland (2010) (ECHR 2032), http://www.bailii.org/eu/cases/ ECHR/2010/2032.html.

9. 'Silence' in Irish abortion (limited or not) has never been put to the Irish people.

I consider the Constitutional cases, in Irish and international courts, challenging the Eighth Amendment to the Constitution and the law, or lack of law, that follows from it.

I bear in mind the many women batted about' from court to court in individual cases, their lives, their griefs, and hurts exposed, judged, rarely remedied. Some we know by name, others only by a letter - strange alphabet of human woe and the frigid impartiality of the law.

I see in my mind's eye the thousands upon thousands of women who have been forced to travel abroad to access abortion, a constant stream, every day, every week, every year from all over the country. ${ }^{11}$

I weep to think of the women and the couples, forced to carry a pregnancy to full term despite a fatal foetal anomaly. I weep at their enduring pain, caused by the gratuitous cruelty of a law which is indifferent to suffering.

I wonder often about the lives of the countless numbers of women over the years and even now as I write, who want to but cannot travel to access abortion: migrant women with documentation difficulties, or facing uncertain exit and re-entry permits; disabled women and women too incapacitated or too ill to travel; women whose family or work responsibilities mean they cannot travel; women who haven't the money to travel; women who cannot even tell their partners or families. There is any number of reasons preventing

10. Technically, there have been five referendums as the 1992 referendum put three potential amendments to the electorate, of which two were passed, i.e. the rights to travel and to information. In both 1992 and 2003, the electorate rejected proposals to further narrow the grounds for abortion in Ireland. Only in Malta and Andorra is the abortion regime as tough as in Ireland.

11. At least 3,679 women accessed abortion in Britain in 2012, and over 158,252 women have had to make the journey since 1980 . These statistics are for women who gave Irish addresses. It's not known how many women from Ireland gave UK addresses, or accessed abortion in other countries, such as The Netherlands. See Irish Family Planning Association. https://www.ifpa.ie/Hot-Topics/Abortion 
women from going abroad for an abortion, and all of them signify denial of the basic human right to access the health services we need, specifically abortion. ${ }^{12}$ We'll never know how many women had to go ahead with an unexpected pregnancy because they had no choice. We'll never know their names, or their stories, but they're there.

I weep again when I think of the devastating case of Ms Y, a vulnerable young asylum seeker who discovered not long after she arrived here that she was pregnant as a result of rape in her home country. She repeatedly requested an abortion during the first months of her pregnancy, but this was refused although she was suicidal. Eventually, Ms Y was forced to have a caesarean section at 24 weeks. ${ }^{13}$ Her body was treated as a mere vessel, her tender young life utterly disregarded.

I remember above all the women who did not survive. The women whose deaths occurred because they were refused an abortion. We know the names and stories of some of these women, but not all of them I feel sure. ${ }^{14}$

12. For many women, provision of the abortion pill (Mifepristone) would be a straightforward solution. However, it is illegal here.

13. All along, Ms Y had said she wanted an abortion.

14. Sheila Hodgers (d.1983) died screaming in agony of multiple cancers. She and her husband had been repeatedly refused an abortion, induction or caesarean section throughout her pregnancy because, the hospital said, the baby would not survive. Their baby girl died immediately after birth. Sheila died two days later. Savita Halappanavar (d. 2102) was about 16 weeks pregnant when she developed back pain and was admitted to hospital. She was found to be miscarrying but was refused an abortion as the hospital said 'the foetal heart was still beating'. She died a week later after miscarrying, contracting E.coli leading to septicaemia. Her husband maintained she would have lived had.$/$

\section{Annáiremór. The great shame.}

Their deaths make me very sad.

I am also angered by a society, a system, a State that places so little value on the life of a woman, that treats her - us - with such contempt. I know Ireland is not unique in this regard. I hold no candle for Irish 'exceptionalism'. But it's the place I grew up in and the place I know more viscerally than anywhere else. I know the scars it can leave on bodies and lives, and I know how it tries to bury, hide and deny. I detest the silences and the silencing. I protest at the inhumanity of the silencers. I resist and refuse their power and control.

In my head, en filigrane, I hear the voices of these women denied, voices at the edge of my consciousness, sotto voce, haunting, uncomprehending. Why did they have to die?
"What would happen if one woman told the truth about her life? The world would split open."16

And then we could speak above and beyond the silence.

We have already started to speak plainly about the facts that matter, and the realities of our lives. We will not stop until we are free to make decisions about our reproductive lives for ourselves.

March 2015

$\%$ their request for termination been met. See Kitty Holland Savita: The Tragedy that Shook a Nation. 2013. Dublin: Transworld Ireland.

15. This brings me back to my starting point. I can't readily answer that question. Maybe it's because, having been involved for so long, I've lost sight of the key to understanding. It isn't simple, in any case.

16. "Käthe Kollwitz” (Rukeyser 2005: 463).

\begin{abstract}
Ailbhe Smyth is an activist and former academic who has been involved in feminist, LGBT, and radical politics for a long time. The founding director of the Women's Education, Research and Resource Centre (WERRC), she was head of Women's Studies at UCD from 1990 until 2006 when she left UCD to work independently. She has lectured and written extensively on feminist issues. She is Convenor of the Coalition to Repeal the Eighth Amendment and a founding member of Marriage Equality. She is currently campaigning for the civil marriage equality referendum. In March 2015 she received the 'Lifetime Achievement' award at the GALAS 2015, the first time the award has been made.
\end{abstract}

